\title{
9. SEDIMENTOLOGICAL STUDY OF CORES 138 TO 56 (UPPER HAUTERIVIAN TO MIDDLE CENOMANIAN): AN ATTEMPT AT RECONSTRUCTION OF PALEOENVIRONMENTS
}

\author{
P. Ch. de Graciansky and P. Y. Chenet, Ecole Nationale Supérieure des Mines de Paris, \\ Centre de Recherches de Géologie Générale et Minière, Paris, France
}

\begin{abstract}
This paper provides tentative reconstruction of paleoenvironments represented in the Cretaceous series which was drilled south of Vigo Seamount near the latitude of the town of Porto (Portugal). Based on mineralogical, petrological, paleontological, and sedimentological data, this stratigraphic sequence may be divided into two main units.

The underlying unit, Hauterivian-Aptian in age, comprises thin sand-silt-clay graded sequences associated with grain flows and mud flows of olistostromal character. Detrital material was derived from continental, outershelf, slope, and underwater fault scarp sources. Many sedimentological features at Site 398 correspond to those of the outer portion of a submarine fan deposited on a subsiding sea floor. The sequential evolution of the calcite content and of the preservation and relative concentration of foraminifers (benthic, planktic, arenaceous) and nannofossils within individual sequences suggest that the sedimentation depth had reached the CCD at the end of the Barremian and exceeded it in the latest Bedoulian. The basement rocks beneath this series consist of tilted blocks affected by synsedimentary movements as recorded by slight superimposed synsedimentary unconformities (Group Galice; this volume) and by the reworking of material from older beds.

The overlying unit (Albian-middle Cenomanian) is bounded at its base by a hiatus or by a condensed layer. This unit consists mainly of black shales with various proportions of redeposited marly chalks. The depth of sedimentation was constantly deeper than the CCD. The main part of the sedimentary supply in the black shales comprises quartz, feldspar, kaolinite, illite, chlorite, and montmorillonite together with plant debris and sporomorphs of continental origin. The accumulation of the black shales on gentle slopes succeeded in smoothing the relief and progressively burying the remaining highs. The series is interrupted towards the top by a hiatus (CenomanianSantonian) and is overlain by carbonate-poor, clinotilolite-rich red clays (Maldonado, this volume) of Senonian age.
\end{abstract}

\section{INTRODUCTION}

Most of the Cretaceous strata of the complex continental margin of Portugal were nearly continuously cored at Site 398, on the southern flank of Vigo Seamount. Hole 398D was located 3910 meters below sea level and penetrated 1742.5 meters below the sea floor (Figure 1).

The Cretaceous series of Hole 398D (Cores 138 to 41), which extends to Hauterivian beds, is divided into two parts by an unconformity, across which the upper Cenomanian, Turonian, and (?) lowermost Senonian are missing. The part which underlies the break is studied here from the sedimentological point of view with the purpose of making a tentative reconstruction of sedimentary paleoenvironments.
In this part of the Cretaceous, the main lithostratigraphic units which were defined by the shipboard scientists (Table 1, back pocket, this volume) are the following:

IVa - Upper-middle Albian to Cenomanian redeposited marls and chalks: Cores 56-2 to 78,947 to 1183 meters (256 m thickness)

$\mathrm{IVb}$ - Lower to lower-middle Albian black shales: Cores 79 to 102,1183 to 1400 meters $(217 \mathrm{~m})$

IVc - Upper Barremian to Aptian sand-silt-clay graded sequences: Cores 103 to 130,1400 to 1667 meters $(267 \mathrm{~m})$

V - Hauterivian to lower Barremian laminated marlstones and radiolarian-bearing white limestones: Cores 131 to 138,1667 to 1742.5 meters $(75.5 \mathrm{~m})$ 


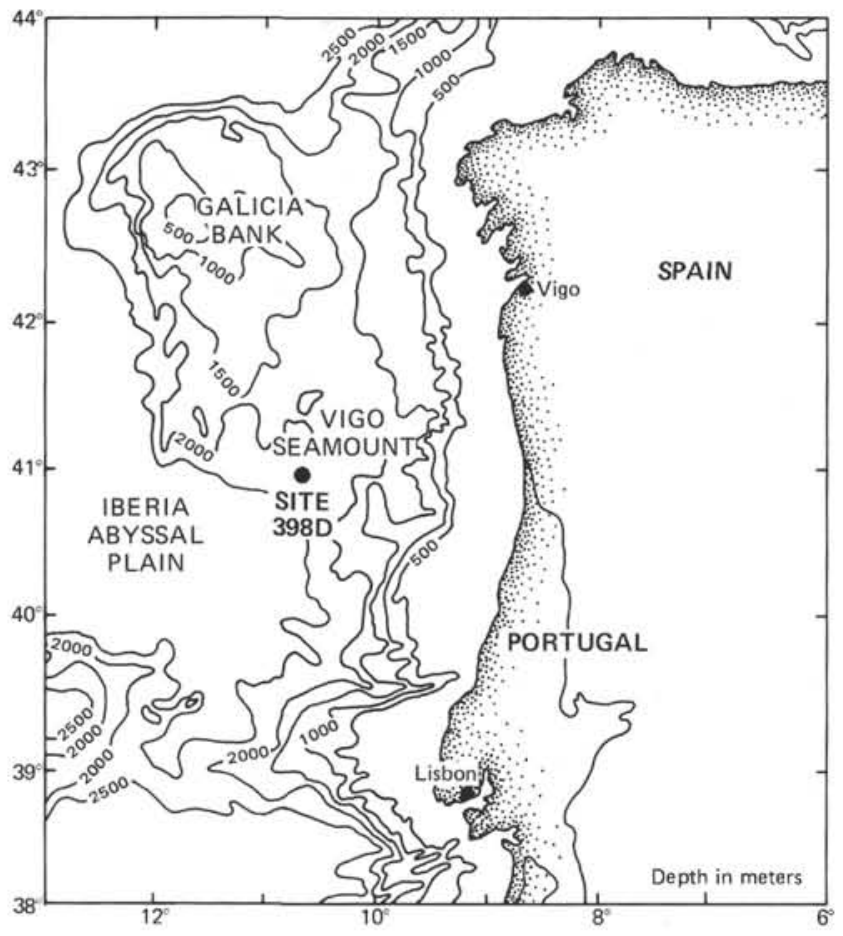

Figure 1. Location of Hole 398D.

The evolution of the relative sedimentation depth with respect to calcite compensation depth was estimated in favorable circumstances. The origin of the sedimentary supply has been discussed, as well as the relations between sedimentation and tectonics. Pertinent geologic information was obtained from the shipboard scientists reports, from the visual core descriptions, and from core photography. Specific sampling of selected sequences was done during the post-cruise meeting held at the Lamont-Doherty Geological Observatory in May of 1977.

Important sedimentological and micropaleontological observations are summarized in Table 1 (back pocket, this volume). The main types of sediment sequences are represented on Figures 2 and 3; the spacing of the main lithological features in Cores 138 to 103 is shown on Figure 4. Figure 5 depicts the result of vertical sequence analysis in Bedoulian and upper Barremian cores, Figure 6 is an interpretative sketch of the entire structural section at Hole 398D. Debris flow, graded sequences, and slumping are represented by the photographs of Figures 7, 8, and 9, respectively.

\section{DESCRIPTION OF MAJOR SEDIMENT INTERVALS OF THE HAUTERIVIAN TO CENOMANIAN SECTION}

\section{Alternating Laminated Marlstones and White Massive Nannofossil Limestones (Cores 138 to 131)}

Age: late Hauterivian to early Barremian (Unit V of Site Report, Unit 1 of Sigal; both, this volume)

Depth: 1667.5 to 1742.5 meters

Thickness: 75 meters
Lithology: White indurated limestone and marlstone/ siltstone may define complex sequences.

The white limestone beds average 10 to $30 \mathrm{~cm}$. They are white to bluish white to very light gray and do not show internal sedimentary features other than obvious burrows. As may be deduced from shipboard core photographs, the upper and basal contacts with the interbedded marlstone and siltstone are gradational through millimetric to centimetric laminations. Basal contacts are erosional in some places. In the thin sections, mainly calcitized radiolarians are scattered within homogeneous calci-micrite, together with sparse phosphate grains (fish debris?), sponge spicules, and "filaments." The calcite content may reach 90 per cent, including 40 per cent nannofossils, which generally are recrystallized severely (Blechschmidt, this volume).

This sediment, even though partially resedimented, might have been deposited under typical pelagic conditions.

Marlstone and siltstone layers, on the contrary, probably were emplaced by turbidity currents flowing into quiet upper environments (Maldonado, personal communication). Prevalent varve-like laminae are composed of alternating white nannofossil-bearing limestone with clay, silt, or fine sand-sized detritus, or with mixtures of calcareous, siliceous, or argillaceous material. Sedimentary features such as parallel, oblique, or convolute laminations and small-scale cross-bedding are very clear on the coarser laminae; the fine-grained layers generally show parallel internal laminations. The terrigenous influence is evidenced by the presence of detrital quartz, mica, $\mathrm{K}$-feldspar, and plagioclase together with montmorillonite ( 50 to $60 \%$ ), illite (30 to $40 \%$ ), chlorite (10 to $20 \%$ ), and minor kaolinite.

The sorting effect of currents inducing lamination is obvious. Thus, in each of the 81 samples studied by J. Sigal for micropaleontological purposes, one of the main components (coarser than $64 \mu \mathrm{m}$, i.e., radiolarians, foraminifers, quartz, mica, organic debris) largely exceeds all others in abundance. For example, a radiolarian-rich washed residuum contains only traces of benthos; no mica, quartz, or plankton; and few aptychus and fish debris. Another sample which is quite quartz-rich shows only traces of benthos, plankton, and radiolarians; no mica; and little plant, aptychus and Inoceramus debris. More precisely: 32 samples have abundant to very abundant radiolarians with (5 cases) or without (27 cases) shells, aptychus or plant debris and phosphatic grains; 14 samples contain radiolarians together with abundant to common benthic foraminifers; 18 samples are rich in quartz and 9 are rich in mica + quartz-rich; 7 samples are rich in planktonic foraminifers (only from Core 133 upwards, for evolutionary reasons); 4 samples contain mostly shell, plant, and phosphatic (fish?) debris.

Normal pelagic sedimentation was represented by radiolarian and coccolith-bearing calcareous muds. The continuity of this deposition was interrupted by the emplacement of two types of turbidity currents, high density and low density (Maldonado, personal communication). These currents transported the minor 
clastic influx of this unit and reworked previously deposited calcareous muds (as shown by intrabasinal mud chips in the turbidites). The environment may correspond to the distal part of a deep-sea fan which appears clearly in the overlying unit.

\section{Graded Sequences in Deep-Sea Fan Environment (Cores} 130 to 103 )

Age: late Barremian to Aptian (Sub-unit IVC of the Site Report; Unit II of Sigal; Table 1)

Depth: 1667.5 to 1401.5 meters

Thickness: 266 meters

Lithology: In this unit, radiolarian-bearing white nannofossil limestone are absent. Two kinds of sequences have been observed: thin $(0.1$ to $1 \mathrm{~m})$ sand-siltclay graded sequences (Figures 2, 3, and 4), interbedded with thick (up to several meters) slumped beds or debris flows (Figure 4).

Among the thin sand-silt-clay graded sequences, there are two end members, depending on the provenance of the detrital supply. One is clearly of continental origin as characterized by abundant quartz, mica, and plant debris; it is generally azoic. The other is derived from slope and outer shelf sources, and contains minor terrestrial material and more unspecified carbonate grains together with benthic and planktonic foraminifers. With few exceptions, radiolarians are ubiquitous. Burrowing may be encountered in either facies.

\section{Characteristics of the Thick Chaotic Beds: Slumped Beds and Debris Flows}

Nine isolated or grouped thick chaotic beds are intercalated within the thinner sequences. Many parts of them show dispersed pebble-to-granule-size fragments in a muddy matrix of marl composition. They are 2 or 3 meters thick (e.g., Cores 124 and 125, Section 128-4, etc.). They are generally overlain by a very well graded calcarenite as already noticed in similar sequences (Remane, 1970; Beaudoin et al., 1975, in redeposited bed of Tithonian age, French external Alps). Plant fragments are common in this graded calcarenite (i.e., Section 128-4).

In Section 105-1 (Figure 9), surprisingly well-preserved fragments of folded layers suggest the slumping of partially indurated calcareous beds.

Study of calcareous fragments from these debris flows, show evidence of reworking of shallow-water deposits, such as oolitic and oncolitic limestone and numerous fragments of thick shells. They also show evidence of the reworking of older pelagic type deposits, such as calpionellid-bearing limestone (late Tithonian and Berriasian: see age determination by Bourbon, this volume); radiolarian-bearing limestone (Hauterivian or older); displaced foraminifers as suggested by abnormal associations (Sigal, this volume); carbonate-free claystone; deformed nannofossil-chalk, etc., the main reworked lithofacies of which has been summarized by Bourbon (this volume). Reworked Cretaceous shallowwater and calpionellid-bearing limestone already have been dredged in the area of Vigo Seamount (Dupeuble et al., 1976).

\section{Organization of Turbidite Sequences}

As used in this paper, a sedimentary sequence is defined by an upper and a lower sedimentary break, which is of erosional origin. The internal grading and other sedimentary features (Figure 3 ) are indicative of turbiditic emplacement. We tried to apply to the Aptian series the sequential analysis technique of Mutti and Ricci Lucchi (1972) and Ricci Lucchi (1975) for Alpine and Pyrenean flysch series in northern Italy and northern Spain. These authors attempted to relate both sedimentological features and sequential evolution of bed thicknesses with steepness of slope and the different parts of a deep-sea fan (Figures 3 and 4). This technique has been applied with success to the study of other sequences, such as the Swiss Prealpine flysch (Van Stuijvenberg et al., 1976).

Minor sequences: As for the thin elementary sequences which have been previously defined in Cores 130-103, they may be grouped in several negative (i.e., thickening upward) "minor sequences" (Ricci Lucchi, 1975), each one a few meters thick at most. In Core 122, there is a group of three negative sequence which define a small major negative sequence (Figure 5A). Together with the implied facies, this may indicate emplacement on the outer part of a fan provided this interpretation is possible on the basis of a single core.

Isolated sequences: Thick debris flows (e.g., Core 128 , Figure $5 \mathrm{~B}$ ) are interbedded within the minor sequences. Emplacement triggered by movements along unstable flanking fault scarps is suggested. Isolated carbonate-rich mud flows were emplaced before the thick grain flows of Cores 104, 105, 106, as suggested by abnormally high $\mathrm{CaCO}_{3}$ contents in several muddy intervals (Cores 109 to 107).

\section{Reconstruction of the Paleoenvironment}

It appears that the upper Barremian-Aptian part of the Hole 398D (Cores 103 to 130 ) was emplaced by turbidity currents on the outer part of a deep-sea fan.

According to A. Maldonado (personal communication), the basal sequences fit the model of a submarine fan in which the better-represented facies are natural levee and interchannel deposits (Cores 131 to 124) followed by a "foot of slope" environment (Cores 123 to 103). This interpretation is in good agreement with facies types, with organization into sequences, and with observations on present-day fans (Maldonado and Stanley, 1975; Rupke and Stanley, 1974). Any more precise reconstruction would certainly be conjectural, since there are no data on lateral continuity and on the relationship among the lithofacies.

\section{The Black Shales (Cores 102 to 79 )}

Age: early Albian to middle Albian (Unit IVb of Site Report, Unit III of Sigal, both, this volume)

Depth: 1183 to 1401.5 meters

Thickness: 218.5 meters

Lithology: The lithological types are less diversified than in the underlying beds (Figures 2 and 3). Thin 
P. CH. DE GRACIANSKY, P. Y. CHENET

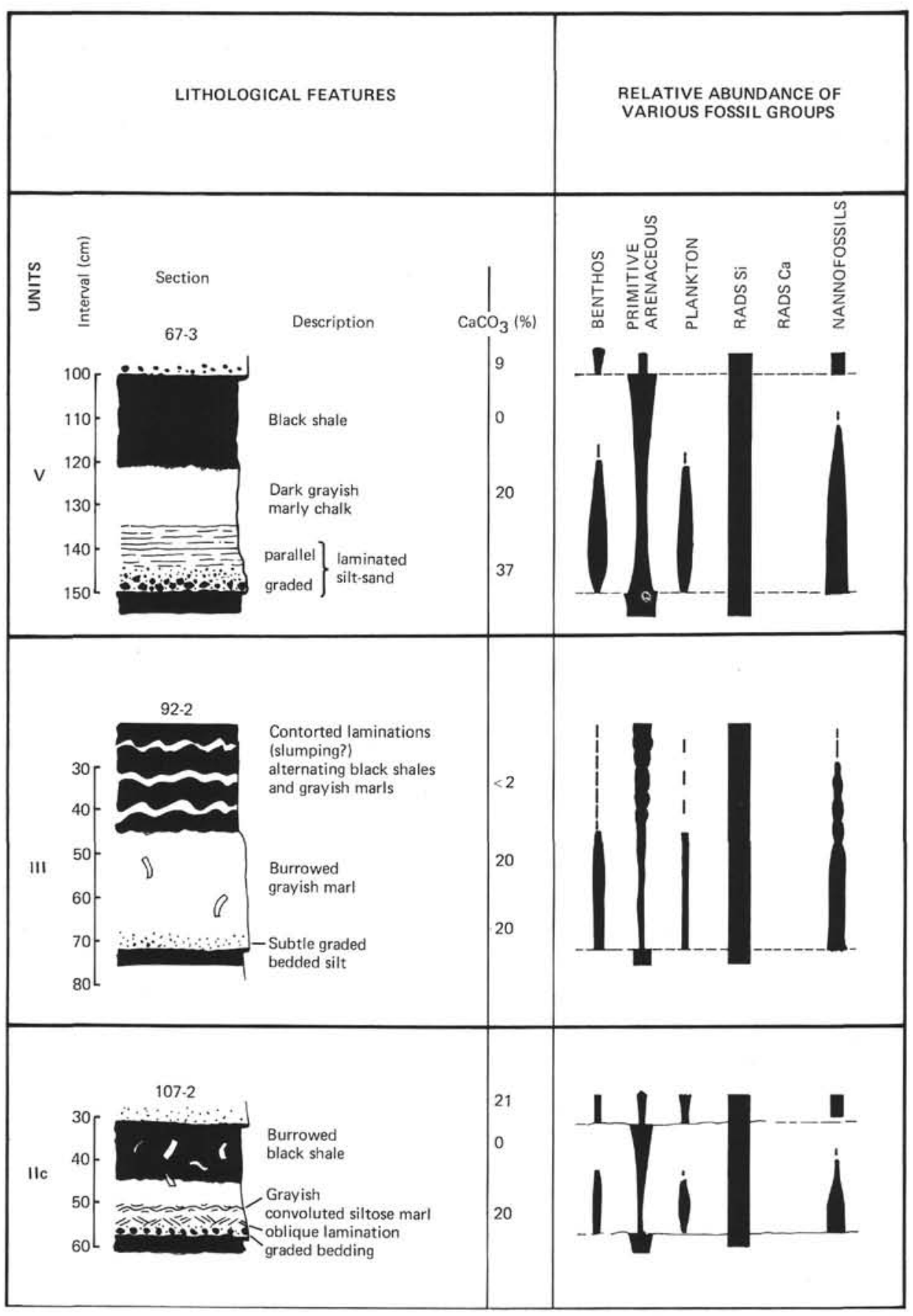




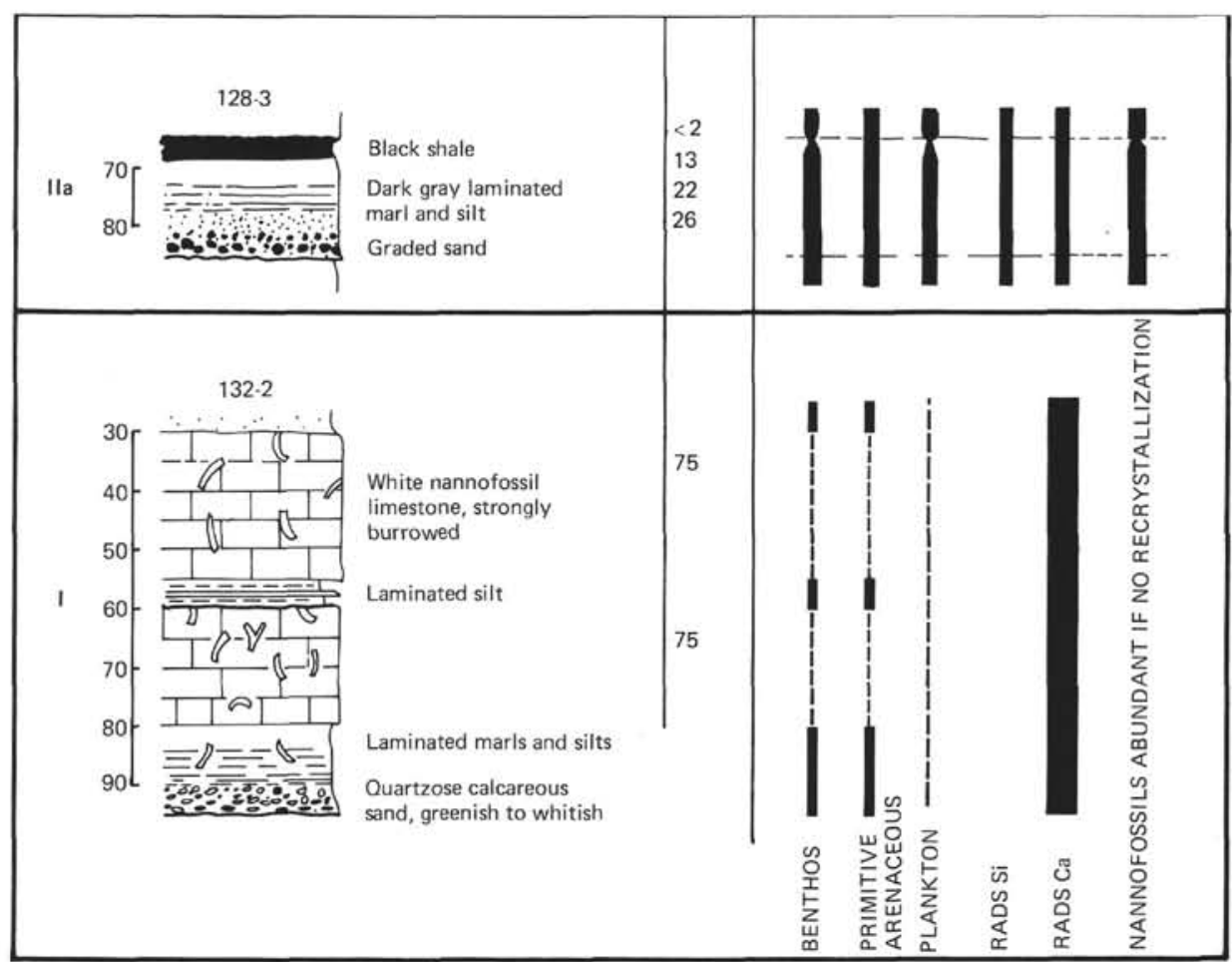

Figure 2. Main sequence types in Hole 398D, Cores 138-57. A special comment is devoted here to the graded sequences of Unit II. The lower one (Core 128) was probably deposited near the CCD; the two others were clearly emplaced deeper than the CCD. Benthos, plankton, and nannofossils are encountered in at the lower part of the sequences, which are relatively calcareous rich. Primitive arenaceous foraminifers tend to be concentrated in the $\mathrm{CaCO}_{3}$-poor claystones, at the top of sequences. Radiolarian shells remain siliceous when the sedimentation was deeper than the CCD (determination by Sigal and C. Müller). The sequence thickness are 5 to $40 \mathrm{~cm}$ thick and average $15 \mathrm{~cm}$. Common sedimentary structures are grading (present or subtle at the base of the sequences); basal surfaces with sporadic scour and fill marks; sporadic clay chips in the sandstone part; coarse to thin laminae (parallel to oblique current); convolute laminations and burrowing (mainly in the upper part of the sequences). The sand shale ratio is low to zero. This unit's classification is $D_{2}, D_{3}$, and $G$ of Ricchi-Lucchi (1975) and Tade, Tce, Tde, and Te of Bouma (1962). Carbonate-depleted hemipelagites are represented in black, marls in white, silts by dashes, sands and graded sandy by dots. Burrows are drawn like worms within the sediment. 


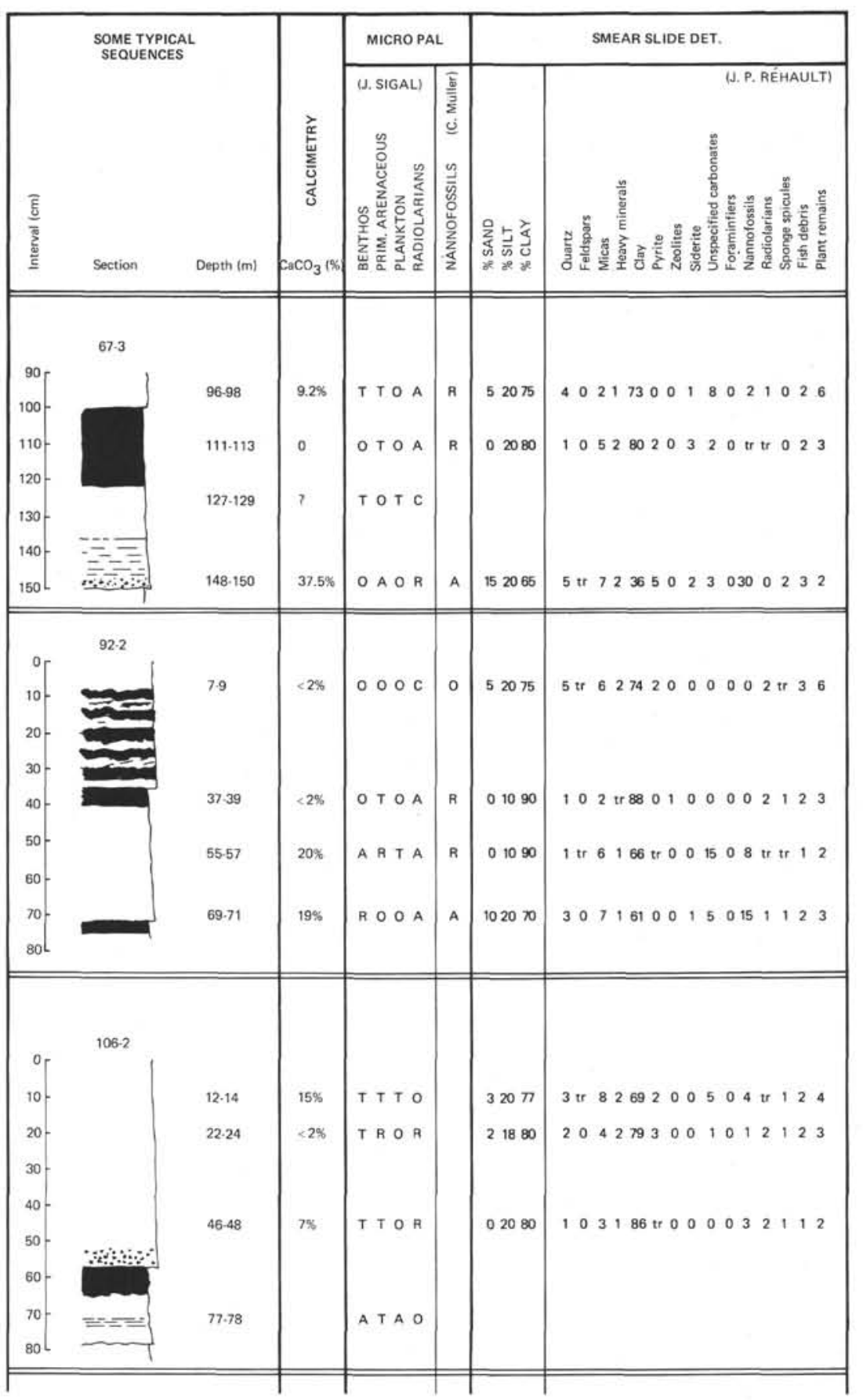

Figure 3. Some typical sequences of the main sedimentary units from the Cretaceous part of Hole 398D. Precise $\mathrm{CaCO}_{3}$ content, estimated microfossil abundance, and approximate percentages of mineralogical components are given here for the main facies in some typical exemplary sequences. $A=$ abundant, $C=$ common, $R=$ rare, $T=$ trace, and $\mathrm{O}=$ zero. $\mathrm{CaCO}_{3}$ per cent determination and smear slide examination were conducted by J. P. Réhault; foraminifer estimation, by J. Sigal; nannofossil determination is by C. Müller. 


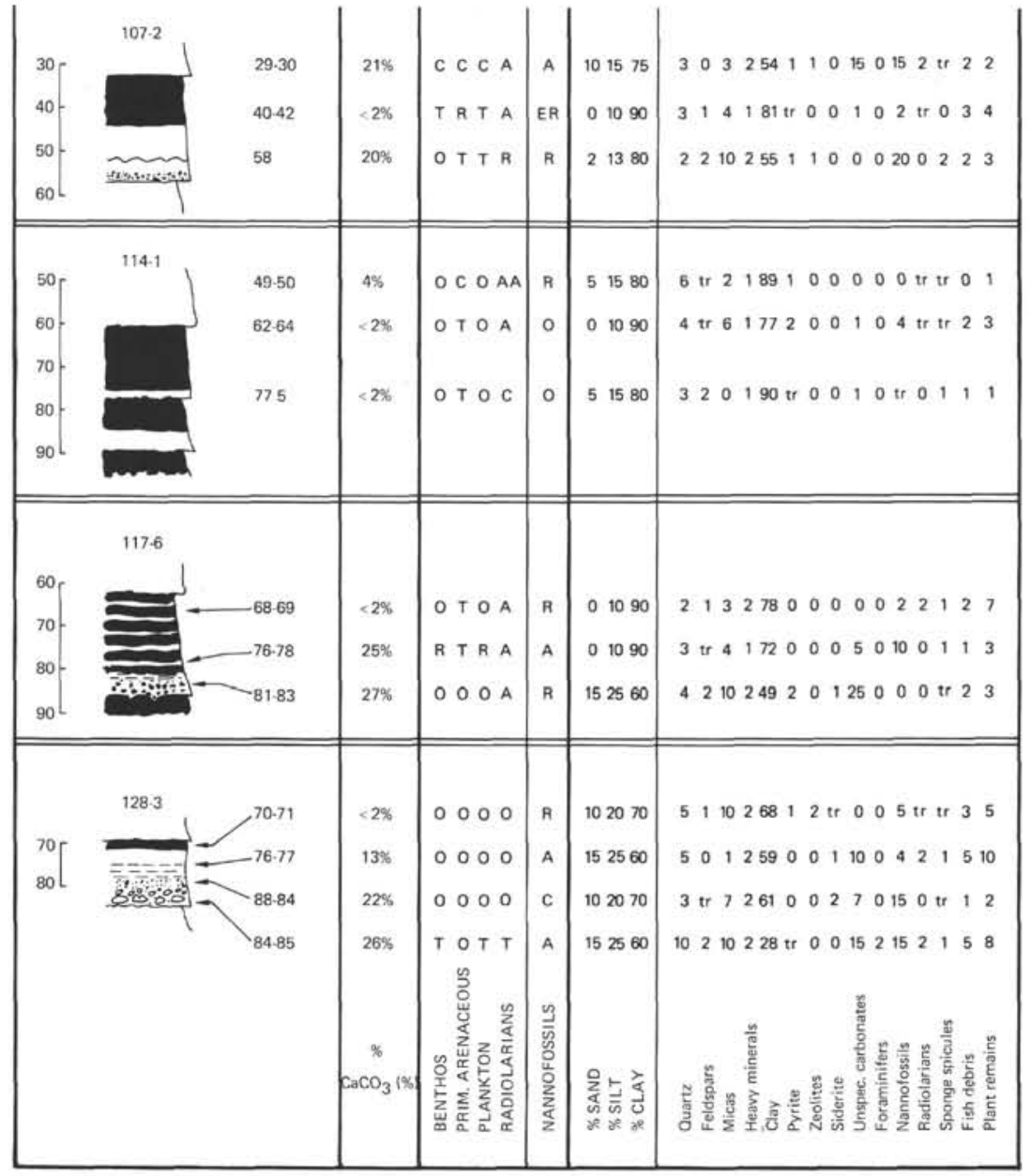

Figure 3. Continued. 


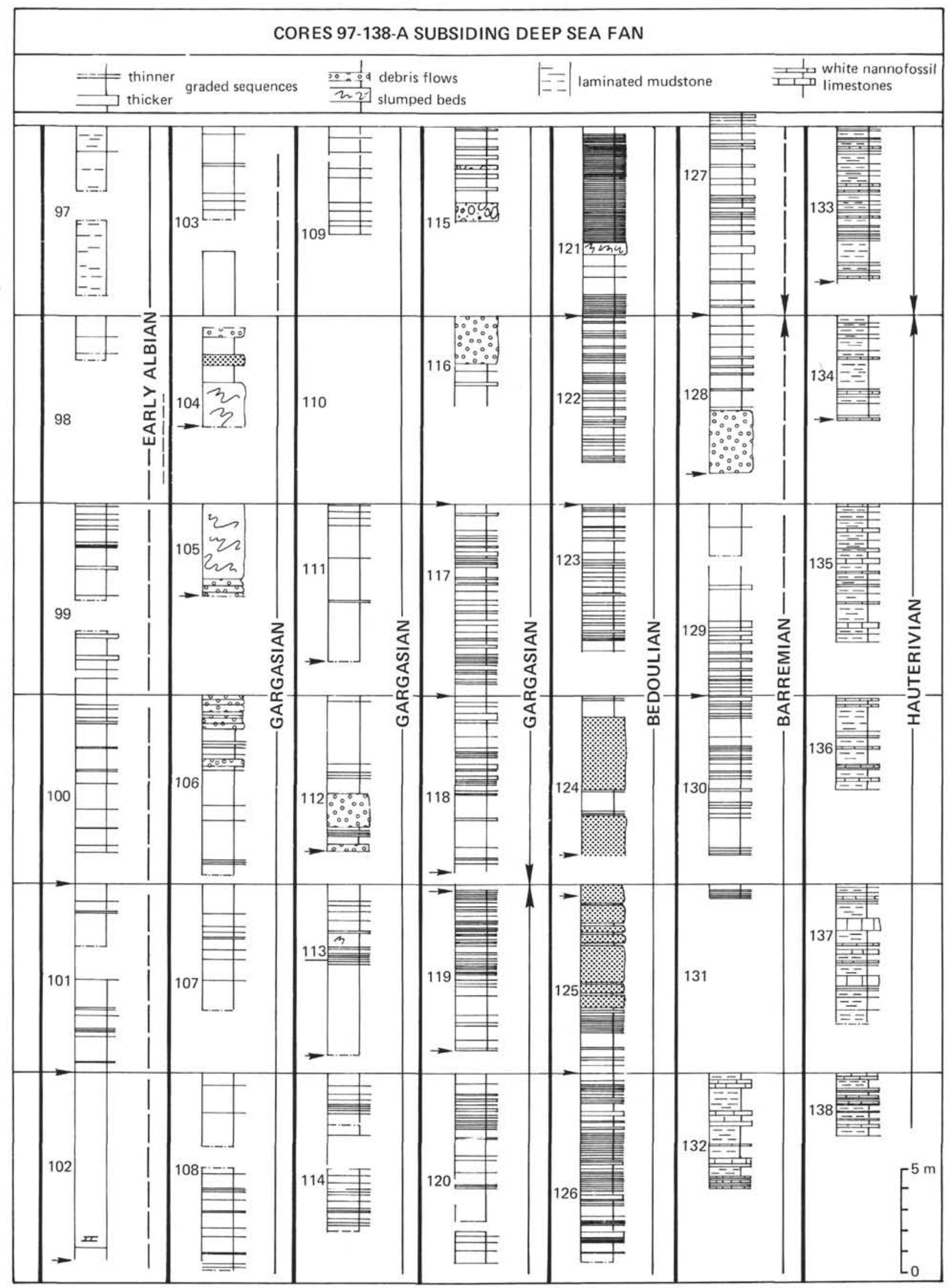

Figure 4. The spacing of main graded sequences of Hole $398 D$ which are Hauterivian to early Albian in age. 


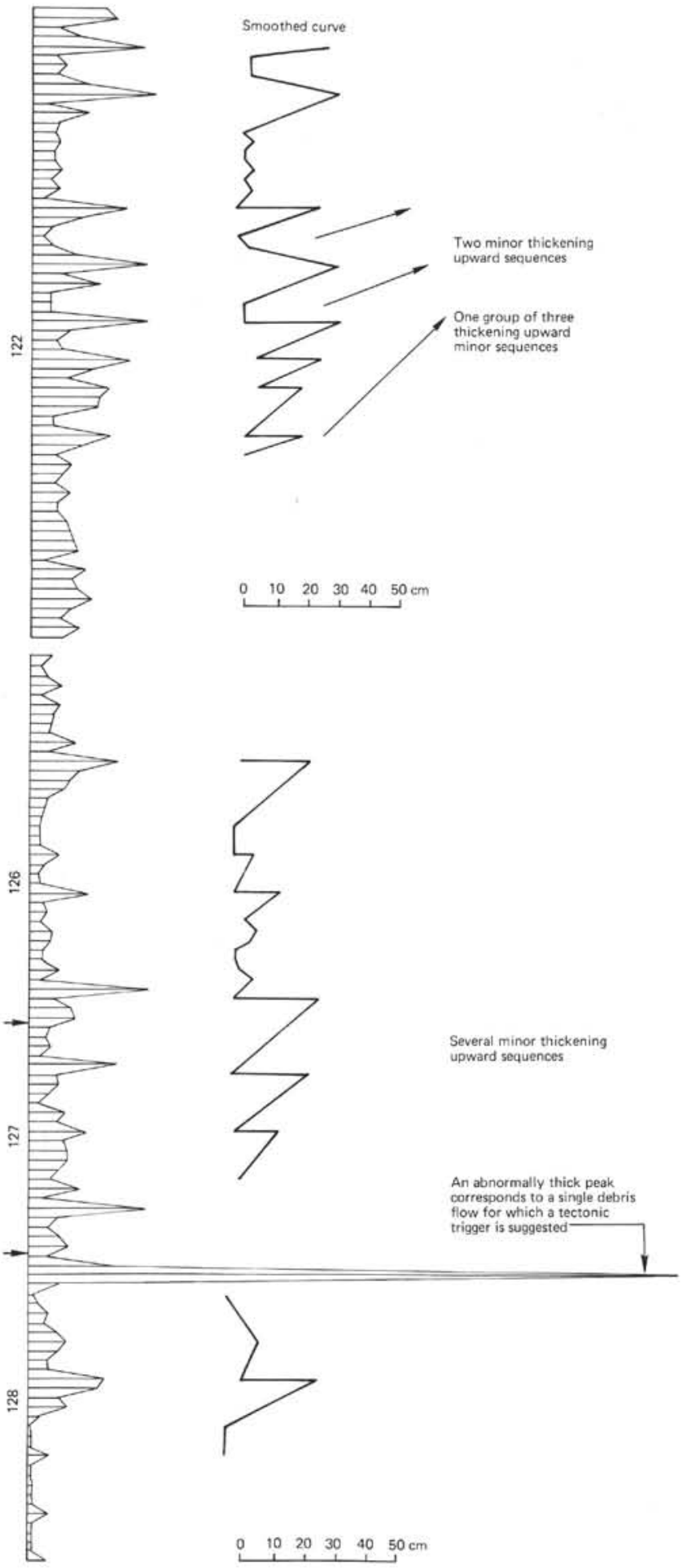

Figure 5. Vertical sequence analysis in Bedoulian and upper Barremian cores. Sequence thickness is on $x$-axis; their rank is shown on the $y$-axis with regular spacing. laminations are present throughout this unit, but they are much less numerous and important than in Cores 138 to 120 . They result from the reworking of black clay and grayish marl. Burrowing is common and, although not clearly linked to any one lithology, it is common in the marls.

\section{Homogeneous Grayish Black Claystone}

These layers are not laminated and poorly burrowed. Their $\mathrm{CaCO}_{3}$ content does not exceed 1 per cent. Planktonic foraminifers are nearly absent; benthic foraminifers are rare and generally corroded by dissolution. Primitive arenaceous foraminifers are relatively concentrated. Fish debris and plant fragments are common. In a few sampled sequences (e.g. Section 92-2), nannofossils are very rare and even resistant species show signs of strong dissolution.

Minor sequences: As for the thin elementary sequences which have been previously defined in Cores $130-103$, they may be grouped in several negative (i.e., thickening upward) "minor sequences"' (Ricci Lucchi, 1975), each one a few meters thick at most. In Core 122, there is a group of three negative sequence which define a small major negative sequence (Figure 5A). Together with the implied facies, this may indicate emplacement on the outer part of a fan provided this interpretation is possible on the basis of a single core.

Isolated sequences: Thick debris flows (e.g., Core 128 , Figure 5B) are interbedded within the minor sequences. Emplacement triggered by movements along unstable flanking fault scarps is suggested. Isolated carbonate-rich mud flows were emplaced before the thick grain flows of Cores 104, 105, 106, as suggested by abnormally high $\mathrm{CaCO}_{3}$ contents in several muddy intervals (Cores 109 to 107).

\section{Reconstruction of the Paleoenvironment}

It appears that the upper Barremian-Aptian part of the Hole $398 \mathrm{D}$ (Cores 103 to 130 ) was emplaced by turbidity currents on the outer part of a deep-sea fan.

According to A. Maldonado (personal communication), the basal sequences fit the model of a submarine fan in which the better-represented facies are natural levee and interchannel deposits (Cores 131 to 124) followed by a "foot of slope" environment (Cores 123 to 103). This interpretation is in good agreement with facies types, with organization into sequences, and with observations on present-day fans (Maldonado and Stanley, 1975; Rupke and Stanley, 1974). Any more precise reconstruction would certainly be conjectural, since there are no data on lateral continuity and on the relationship among the lithofacies.

\section{The Black Shales (Cores 102 to 79)}

Age: early Albian to middle Albian (Univ IVb of Site Report, Unit III of Sigal, both, this volume)

Depth: 1183 to 1401.5 meters

Thickness: 218.5 meters 


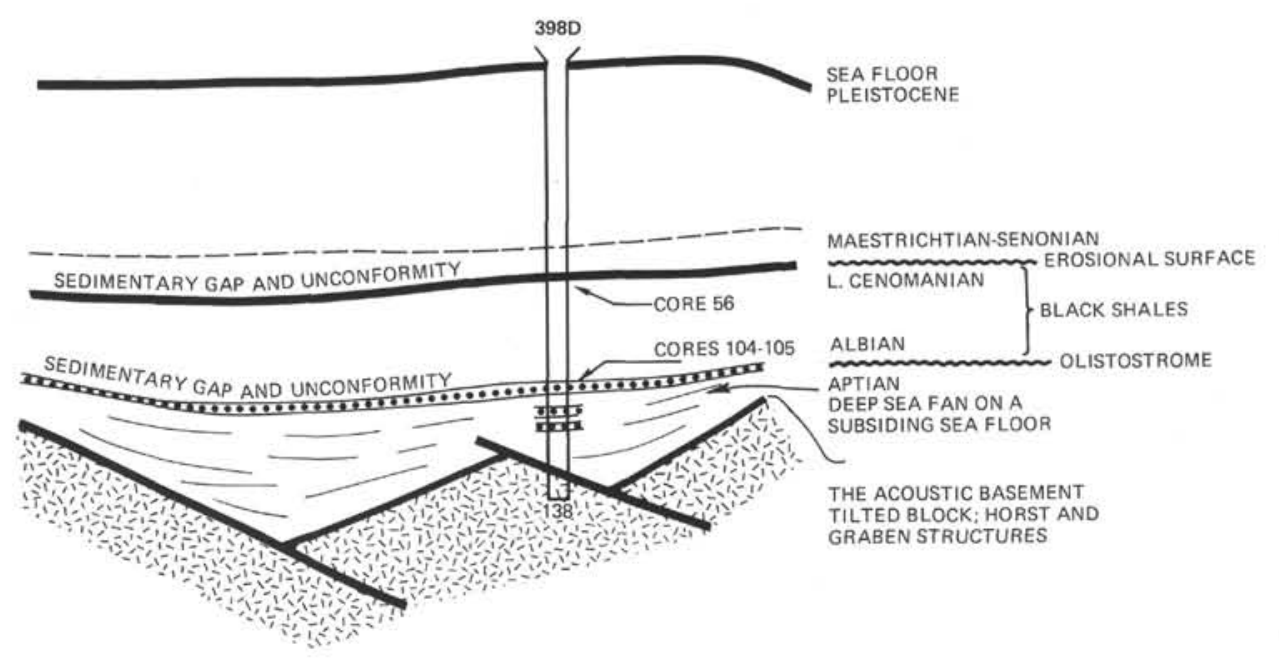

Figure 6. Interpretive sketch structural section of Hole 398D. This imaginative diagram was sketched from J. P. Réhault and Groupe Galice (O. de Chapal) information.

Lithology: The lithological types are less diversified than in the underlying beds (Figures 2 and 3). Thin laminations are present throughout this unit, but they are much less numerous and important than in Cores 138 to 120. They result from the reworking of black clay and grayish marl. Burrowing is common and, although not clearly linked to any one lithology, it is common in the marls.

\section{Homogeneous Grayish Black Claystone}

These layers are not laminated and poorly burrowed. Their $\mathrm{CaCO}_{3}$ content does not exceed 1 per cent. Planktonic foraminifers are nearly absent; benthic foraminifers are rare and generally corroded by dissolution. Primitive arenaceous foraminifers are relatively concentrated. Fish debris and plant fragments are common. In a few sampled sequences (e.g. Section 92-2), nannofossils are very rare and even resistant species show signs of strong dissolution.

\section{Grayish to Olive-Green Marlstone}

Some of these layers are slightly burrowed and laminated. The $\mathrm{CaCO}_{3}$ content may reach or exceed 20 per cent. Planktonic foraminifers are rare in the lower cores (102 to 91 ) and become more numerous in higher cores. Benthic foraminifers are more abundant than planktonic types, and are also increasingly numerous from the bottom to the top of the series; both types commonly show signs of corrosion. Nannofossils may be abundant in this facies, but even resistant species are generally corroded.

Generally, marlstone overlies black claystone along an erosional surface which in some places is marked by thin silt beds. In other places, the basal surface of marlstone is not well defined. From such relationships it may be inferred that the grayish olive-green marlstones were resedimented deeper than the CCD and there interbedded with carbonate-depleted black shales.

\section{Other Features}

The relatively high sedimentation rate $(75 \mathrm{~m} / \mathrm{m} . \mathrm{y}$, compared to the $25 \mathrm{~m} / \mathrm{m}$.y.) in Cores 103 to 130 , the relatively low biogenic or chemical carbonate content, and the abundance of terrestrial plant debris (Habib, Deroo; both, this volume), show that the sediments are mainly of continental provenance. This is confirmed by the average mineralogical compositions which have been computed for the black shales (Chenet and Teil, this volume).

The introduction of the thin layers of terrigenous input might have been rhythmic and probably due to mud flows which were carrying clay, quartz, mica, plant debris, and foraminifers, ammonites, and Inoceramus shells. Sediments were probably also emplaced by turbidity currents, bottom currents, and pelagic settling.

The importance of diagenesis in the black shales is shown by the presence of minerals such as pyrite, gypsum, barite, and siderite. In some places, the siderite occurs as thin beds or lenses up to one centimeter thick, in which the original bedding is perfectly preserved. Such features have been mistakenly identified onboard ship as algal stromatolites, which are supposed to be shallow-water indicators.

An unsolved sedimentological problem in the black shales is the presence of well-preserved ammonite shells (Renz, this volume). They are aragonitic and do not show any dissolution effects, in spite of low $(<2 \%)$ $\mathrm{CaCO}_{3}$ content of the enclosing sediment and the absence of foraminifers (except primitive arenaceous types). Possibly, Ammonite shells were carried rapidly down and buried as parts of purely argillaceous mud flows originating in shallower water.

\section{Intermediate Part: Interbedded Black Shale and Marlstone (Cores 80 to $\mathbf{7 1}$ )}

Age: late middle Albian (Unit IVa of Site Report, Unit IV of Sigal, both this volume) 


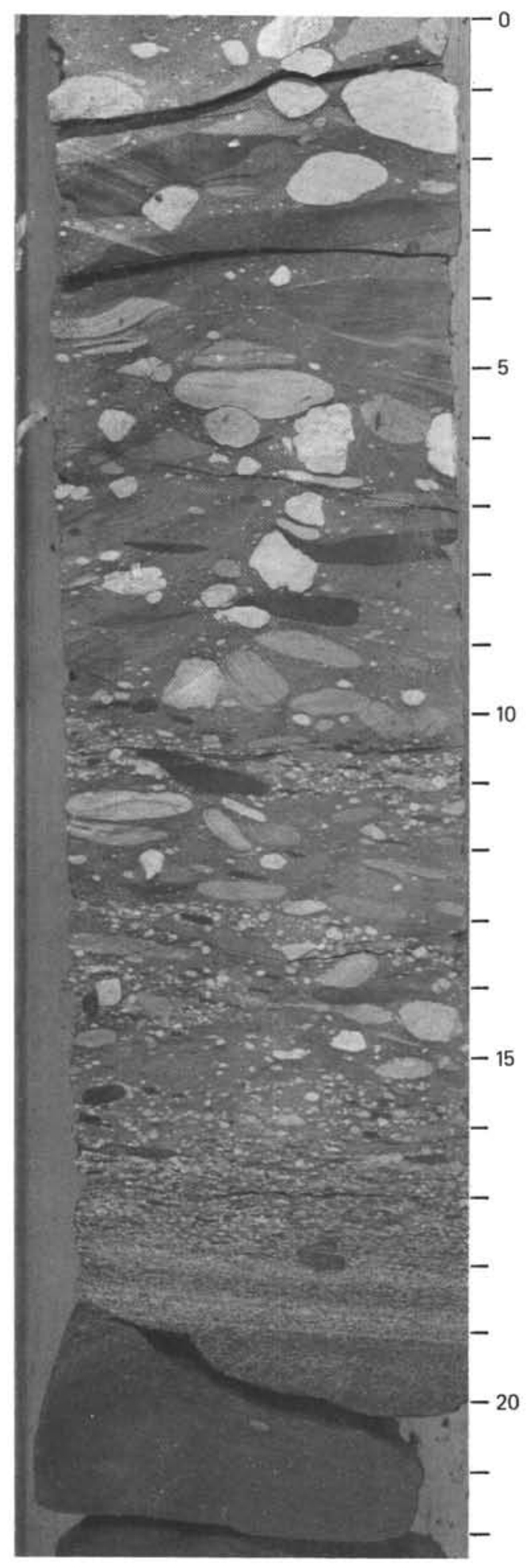

Figure 7. Typical debris flow, Sample 398D-124-4, 7-28 $\mathrm{cm}$. This matrix-supported breccia comprises oolitic limestone, oncolitic limestone, calpionellid-bearing limestone, dark claystone, nannofossil chalk, mud chips, with displaced foraminifers and mollusk shells. Rounded grains show internal flowage and folding due to slumping and transportation in unlithified state Calpionellids and reworked foraminifers are dispersed within the muddy matrix. This breccia is capped by a graded fine-grained calcarenite.

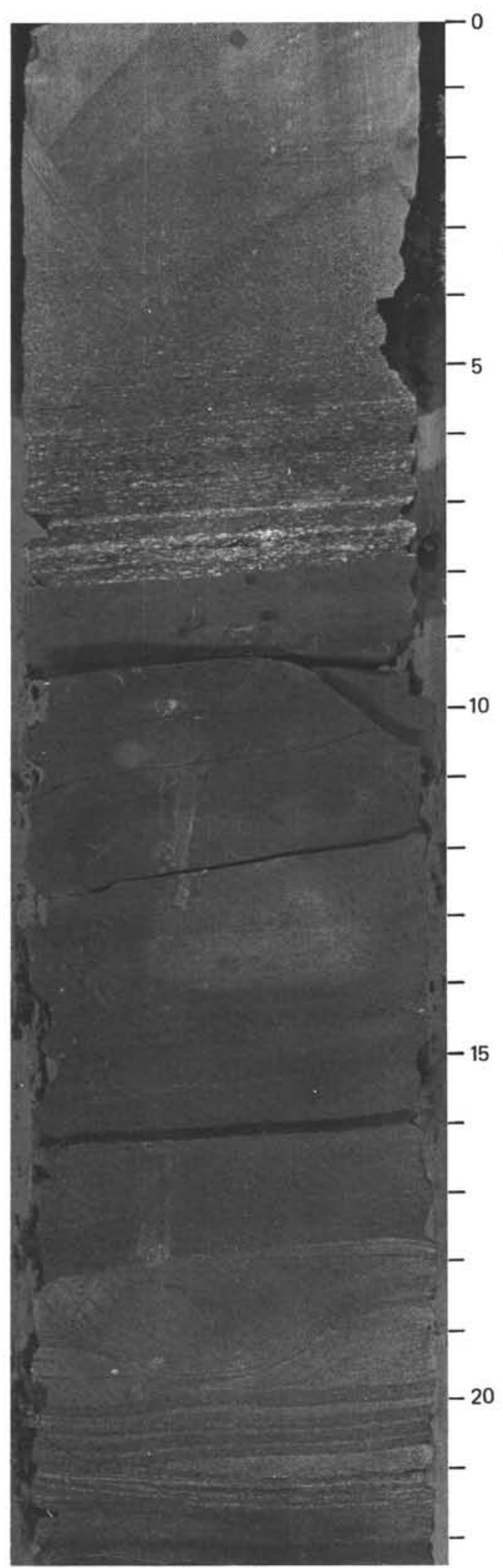

Figure 8. Sedimentary structures within the graded sequences part, Sample 398D-123-4, 1-24 cm. From $9.5 \mathrm{~cm}$ and upwards, a thin graded sequence with some parallel laminations rests on an erosive surface which intersects carbonate-depleted black shale. Between 19 to $21 \mathrm{~cm}$ a slumped bed overlies some parallel laminated beds. 


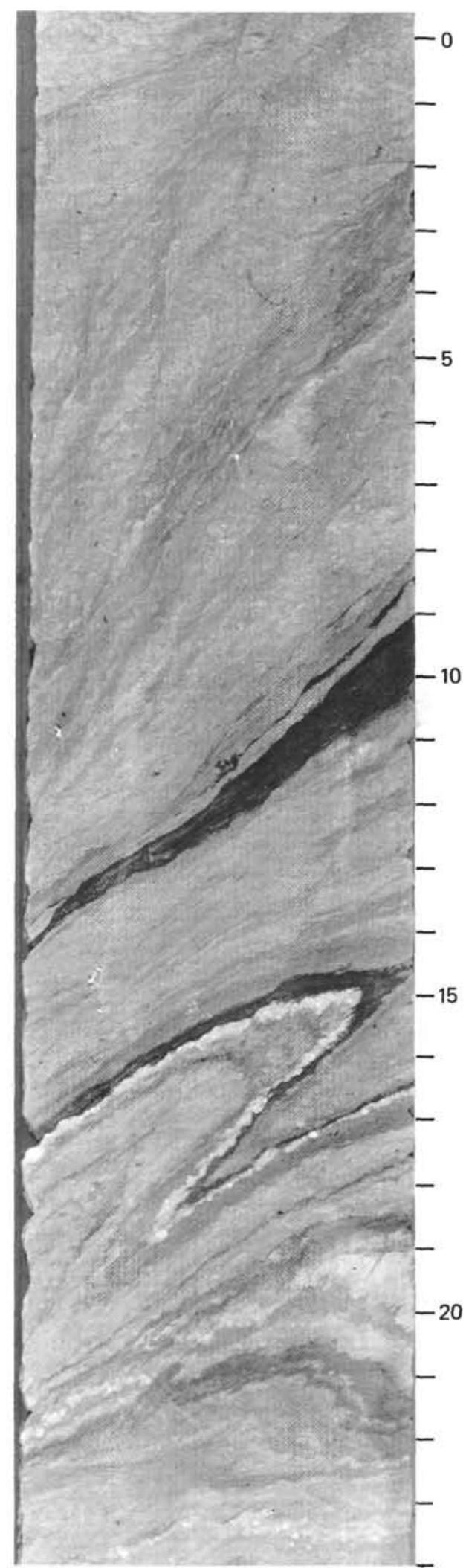

Figure 9. Example of slumping, Sample 398D-105-1, $40-64 \mathrm{~cm}$.
Depth: 1088 to 1201 meters

Thickness: 114 meters

Lithology: Grayish marlstone beds are more numerous and thicker than they were lower in the hole. They are interbedded with black claystones (i.e., black shale). Several lithologic features define this unit: (1) quartz grains are coarser, more frequent, and more abundant than in Unit III, but quartz decreases towards Core 71 ; (2) some marly mud flows are true debrisflows, especially in Cores 79 and 76; (3) bottom-current laminations are increasingly frequent; and (4) attapulgite suddenly appears in Core 79 (Chamley in Debrabant et al., Chenet et al., both, this volume), which probably records climatic changes on the continent. The sudden arrival of attapulgite has been noticed in the middle Albian of several DSDP wells located on the European and African Continental margins (Chamley, in Debrabant et al., this volume).

\section{Pelagic Marl and Chalk (Cores 70 to 56-2, $19 \mathrm{~cm}$ )}

Age: latest middle Albian, late Albian, and Vraconian early Cenomanian (upper Unit IVa of Site Report, Unit V of Sigal, both, this volume).

Depth: 948 to 1088 meters

Thickness: 140 meters

Lithology: Sediment types are not very different from that of the underlying unit. A new feature is that the terrigenous sedimentary supply is very low from Core 70 up to Core 59; then, it is renewed (influx of some rounded sand-size quartz grains). Thus, the dominant sediments are marly nannofossil chalk and calcareous mudstone. Dark, carbonate-depleted claystones devoid of foraminifers are still present, but decrease up to Core 62 and are rare in Cores 60 to 57. In Sections 56-2 to 56-6 basal sediments comprise clay, quartz, and clinoptilolite of diagenetic origin. They are almost devoid of $\mathrm{CaCO}_{3}$ ). Some silty graded marl, with some 30 to 40 per cent $\mathrm{CaCO}_{3}$, is interbedded.

For the underlying black shale, the sedimentary supply was mainly terrestrial, and calcareous muds are quite minor. In this interval (Cores 70 to 56) the situation is quite the reverse. There, terrigenous sand and silt are rare (except for Cores 58 to 56) and the dominant sediments are foraminiferal pelagic marl and chalk. In these sediments, the dominant influence of pelagic sedimentation also is supported by carbon geochemistry (Deroo et al., this volume) and by palynological data (Habib, this volume).

The richly calcareous deposits are interbedded with carbonate-depleted claystone which contains significant amounts of primitive arenaceous foraminifers. In Cores 58 to 56 , microfossils are scarce, owing perhaps both to a temporary terrigenous influx and to diagenetic effects, shown by the development of clinoptilolite.

\section{ESTIMATION OF THE CALCITE COMPENSATION DEPTH: A DISCUSSION}

One relationship between the calcite compensation depth and the sedimentation depth was evaluated from specific characteristics of displaced sediments, especial- 
ly turbidite sequences. Some of the sequences are simple mud flows, a few have olistostromal characters (slumped beds and debris-flows), and a great many are sand-size to clay-size graded (Cores 130 to 103). Special attention was devoted to the upper, hemipelagic, part of the sequences which are the finest grained and which presumably would have come under the influences of corrosive waters if deposited deeper than the CCD. On the contrary, the coarser lower part of the graded beds was protected from dissolution by rapid burial, but yields information on the provenance of the sediments. Thus, carbonate-free hemipelagic sediments may indicate either sedimentation at levels deeper than the $\mathrm{CCD}$, or strong terrigenous influx, leading to purely quartzose and argillaceous sediments. Based on this and previous studies on the $\mathrm{CaCO}_{3}$ content, foraminifers and nannofossils in hemipelagic sediments (Brouwer, 1965; Weidmann, 1967; Kuenen, 1968; Hesse, 1975), we recognize that the microfaunal association comprises three parts. These are: (1) planktonic foraminifers which fall from the overlying sea waters (they are not preserved on a sea floor deeper than the CCD, but if brought down by turbidity currents they may be preserved by rapid burial); (2) calcareous benthic foraminifers find optimum ecological conditions on the shelf and the upper slope and generally do not live in deep water; and (3) for primitive arenaceous foraminifers (which are quite ubiquitous), the nature of their shell protects them from dissolution. Thus, the presence or absence of benthic calcareous versus primitive arenaceous foraminifers does not have exactly the same significance for sedimentation deeper as it does for sedimentation shallower than the CCD.

Table 1 and Figure 2 summarize the vertical changes of $\mathrm{CaCO}_{3}$ content and the foraminifers in both hemipelagic and reworked sediments from Hole 398D.

Hauterivian and lower Barremian strata (Cores 138 to 131) were certainly deposited shallower than the CCD: hemipelagic sediments are represented by radiolarian-bearing white limestone. Planktonic foraminifers appear for the first time in Core $\mathbf{1 3 3}$ for evolutionary reasons. They become abundant above Core 129, but are not very useful in dating these lower cores. The poor preservation of coccoliths (Blechschmidt, this volume) must be interpreted as due to diagenetic dissolution, as suggested also by the abnormal Sr content of limestone (Debrabrant et al.; Renard et al.; both, this volume).

Within and above the upper Barremian, there appear clear graded sequences. For the lower ones, the upper hemipelagic parts are rich in $\mathrm{CaCO}_{3}$ (Unit IIA, Cores 130 to 121 ) and comprise benthic, planktonic, and primitive arenaceous foraminifers. Nannofossils are abundant in some layers. Foraminiferal calcareous shells and nannofossils show traces of dissolution which cannot be related clearly either to diagenesis or to the sedimentation depth with respect to the foraminifer$\mathrm{CCD}$, at least when we consider isolated sequences. In most sequences, planktonic, benthic, and primitive arenaceous foraminifers are met in unchanging proportions from bottom to top.

Sample 128-3, 65-82 cm (Figures 2 and 3) shows graded sand and low carbonate black mudstone towards the top. $\mathrm{CaCO}_{3}$ content grades from 26 per cent to less than 2 per cent from bottom to top. Because quartz and unspecified carbonate make up the main part of the coarse fraction in this sequence, foraminifers are nearly absent. Nannofossils and Nannoconus are abundant, especially the forms which are resistant to dissolution, except in the carbonate-poor uppermost part of the sequence where they are noticeably fewer (C. Müller, personal communication).

The sedimentation depth was approaching the CCD during the late Barremian (Cores 130 to 121). Within and higher than Core 120 (middle Aptian), a clear change appears: thick carbonate-depleted hemipelagic sediments cap the graded sequences. These are nearly devoid of benthic and planktonic foraminifers, but are enriched in (insoluble) primitive arenaceous types (see Table 1). Such conditions persist up to Core 56, as illustrated by several examples which are represented on Figure 3. These observations show that the CCD has been clearly reached and passed by the depth of sedimentation.

The upper boundary for the preservation of nannofossils in the hemipelagic sediments is somewhat higher than that for calcareous foraminifers. Benthic and planktonic foraminifers disappear in Core 120, while nannofossil content decreases across Cores 122-123 and vanishes in Core 116 (C. Müller, personal communication).

There are small proportions of benthic and (more rarely) planktonic foraminifers in hemipelagic sediments from Cores 113 to 106 and from Cores 88 to 70 , even though these strata are supposed to have been deposited deeper than the CCD. Such anomalies may result from the "pollution" of $\mathrm{CaCO}_{3}$-poor claystones, by resedimentation from bottom currents, or by slumping on the sea floor.

As for the relationship between sediment characters and CCD, two more points must be outlined here. First, regarding the aragonitic shells (ammonites and Epistominidae), we carefully examined their debris to find a possible record to the ACD crossing, but all aragonitic shells are contained within redeposited mudstones. The epistominids are commonly corroded, but curiously, ammonite shells are remarkably well preserved. Second, concerning the radiolarian tests (from Sigal's micropaleontological observations; see Table 1 and 2) are the following comments:

1) In sediments deposited shallower than the CCD, radiolarian tests are all calcitized (Cores 138 to 131).

2) In sediments deposited close to the CCD, about half of the radiolarian tests are calcitized while the other half are siliceous.

3) In sediments deposited deeper than the CCD, radiolarian tests remain siliceous in hemipelagic and 
redeposited sediments (except for some reworked calcareous hemipelagic muds where they are calcitized).

\section{CONCLUSIONS: EVOLUTION OF DEPOSITIONAL CONDITIONS AND PROBLEMS OF SEDIMENTARY ENVIRONMENTS}

The series studied was deposited in a pelagic environment and probably in deep water. However, the depositional environment was changing throughout Early Cretaceous time as the type of sedimentary supply, the rate of accumulation, the carbonate compensation depth, and the bottom depths were changing.

The materials deposited in the Cretaceous series at Hole 398D are of the following various origins: (1) the continent provided quartz, feldspar, mica, clay, and plant debris; (2) the shelf and the slope supplied shell debris, comprising Inoceramus shells, benthic foraminifers, and the many kinds of shallow-water carbonate debris in the debris flows; (3) the sea water was the source of radiolarians, planktonic foraminifers, sponge spicules, phosphatic fish debris, and coccoliths; (4) recently deposited sediments resulted in mud flows and the various redeposited hemipelagites; and (5) previously deposited sediments underlying the sea floor, probably cropped out along synsedimentary fault scarps and provided debris flows (e.g., calpionellid-bearing Tithonian cobbles are included in flows on early and late Aptian age.

As shown in Table 1 (back pocket, this volume) terrigenous sediments are well represented in the Aptian (Cores 130 to 103). They dominate in the black shale (early and middle Albian, Cores 130 to 40 ) but nearly vanish upwards. On the contrary, carbonate material (which is well-represented in Aptian Cores 130 to 103) is minimum in the black shale and dominates at higher levels (from Core 70 upward).

The other components, such as chert, pyrite, barite, gypsum, siderite, and zeolites, are of diagenetic origin and are not discussed here.

One of the main interests in the Hole 398D cores is that they show a succession of contrasting lithological units separated by clear sedimentary discontinuities. The sedimentological characteristics, as well as the accumulation rate curve (Ryan and Sibuet, this volume), show that the Cretaceous series is divided by three discontinuities separating the main units within which there are vertical variations.

From Hauterivian to lower Barremian (Cores 138 to 131), pelagic white limestone is interbedded with laminated sand, silt, and clay which was deposited by gentle turbidity currents. The sedimentation depth was shallower than the CCD. The environment is difficult to reconstruct because the lower part of this unit was not drilled. Possibly, it was the foot of the slope, but may be the distal part of a submarine fan. This lithological unit has been identified as a part of acoustic basement (Ryan and Sibuet, Site Report, this volume).

In the lower Barremian (between Cores 130 to 131), a sharp change is defined: radiolarian-bearing white mas- sive limestone disappears as the sea floor depth reached the CCD. The bulk mineralogical content of the hemipelagic sediment changes abruptly, with a decrease in calcite, and the sudden increase of quartz, feldspar, kaolinite, and illite (Debrabant et al., Chenet et al.; both, this volume). At the same time, the sedimentation rate increased. Soon, thick grain flows (which are slope indicators) appear. Thus, we may consider the transition between Cores 130 and 131 as a discontinuity of regional importance, even though the change is subtle from the sedimentological point of view only. In fact, this discontinuity is recorded on seismic profiles as corresponding probably to the top of the acoustic basement. It is most probably caused by some tectonic event associated with a phase of rifting.

From the uppermost lower Barremian (Core 130) to upper Aptian (Core 103), sedimentological characteristics suggest that deposition was on the foot of the slope, probably part of a submarine fan. The calcite compensation depth was approached (Cores 130 to 120) and then crossed (Core 119 and higher).

The regularly rythmic deposition was now and then disturbed by chaotic beds (olistrostromes), which indicate the renewal of synsedimentary slopes and relief, as shown by the reworking of Tighonian cobbles into upper Aptian beds. However, it is likely that the sea bottom at the site of accumulation was quite smooth, partly because of the weak cohesion of reworked sediments deeper than the calcite lysocline (Berger and Johnson, 1976).

It is possible that these slopes were maintained by synsedimentary distensional tectonic events. In fact, according to Groupe Galice (this volume), acoustic Formation 4 (Neocomian to Aptian) was deposited during a time of active faulting related to expansion of the Bay of Biscay. Thus, the reconstructed deep fan history is not that of progradation on an abyssal plain, but sedimentation on a subsiding sea floor and within a complex horst-graben system.

Near the boundary between the Aptian and Albian (Cores 100 to 103) a new sedimentological boundary is recorded on the basis of three observations. First is the last of the coarse-grained turbidite layers and the beginning of massive typical black shale; second is a regional unconformity and probably by a sedimentary gap or stratigraphic condensation (the intermediate sub-stage between Aptian and Albian, the so-called Clansayesian, has not been identified micropaleontologically), and third is a temporary decrease in the sedimentation rate.

From the upper Aptian (Core 102) to the Vraconian (Core 57), black shale which corresponds to acoustic Formation 3 was deposited deeper than the CCD and interbedded with redeposited marly nannofossil chalk. In spite of dissolution processes, the sedimentation rate reached high values (maximum of $100 \mathrm{~m} / \mathrm{m} . \mathrm{y}$.) because of a massive influx of terrigenous sediments with much terrestrial plant debris. The problem of redox conditions on the sea floor in relation to the black color has been discussed elsewhere (de Graciansky, this volume; Ryan and Cita, 1977). 
Sub-divisions in this thick mass of pelagic mudstones are defined by a changing sedimentary supply as follows:

1) In the first division (Cores 103 to 79), terrigenous clay and silt largely dominate.

2) In an intermediate division (Cores 103 to 79), terrigenous clay and silt are in comparable proportions to redeposited marly nannofossil chalk. This division is marked by the arrival of attapulgite (Chamley, in Debrabant et al., this volume).

3 ) In the third division (Cores 70 to 59), probably redeposited hemipelagic marly nannofossil chalk progressively dominate.

4) In a last division, clastic sedimentation resumes (Cores 58 to 56 ).

According to available seismic records, the black shale (acoustic Formation 3; Groupe Galice, this volume) progressively buried early paleorelief and filled previous tectonic rifts while the normal faults that bounded them continued to be active.

Between late Cenomanian and Santonian (Cores 56 to 2), a long sedimentary gap was marked by widespread erosion of the top of the black shale, which had been slightly deformed (Groupe Galice, this volume).

Then, in the Late Cretaceous, red clays were laid down along this erosional surface (for sedimentological study, see Maldonado, this volume). They completely fill depressions by differential sedimentation and then "deposition (took) place on flat surfaces" (Groupe Galice, this volume).

This paper concerns mainly the problems of paleoenvironments of sedimentation, but it has been written in close cooperation with mineralogists, paleontologists, and structural geologists such that it should be read and considered as part of a team effort.

We should like to underline here the complexity of the structural history of the Iberian margin during Mesozoic times. Beyond lithological changes linked to general climatic variations (such as the black shale "event"), this history was marked by increasing synsedimentary movements which maintained and/or created horst and graben submarine structures, with their highs, scarps, slopes, and troughs. These were not smoothed by sediment accumulation from Triassic (?) until Late Cretaceous times. At Site 398, turbidity currents and mud flows progressively built a complex deepsea fan on a subsiding sea floor. The debris was supplied mainly from the continent and partly from flanking submaring scarps and highs. Sedimentation was discontinuous because of the periodical emplacement of huge olistrostromal masses or because of temporary erosional episodes leading to regional or local unconformities. Such processes were a reflection of the general tectonic instability of the passive Iberian continental margin caused by pre-Atlantic rifting and spreading.

\section{ACKNOWLEDGMENTS}

We thank Dr. J. Sibuet and Dr. W. B. F. Ryan, Co-Chief Scientists, for allowing us to conduct this study, and Prof. E. L. Winterer and Prof. L. Contescu for reviewing our last draft. At first, chronostratigraphical and ecostratigraphical data were studied jointly and carefully discussed in close connection with J. Sigal; then C. Müller was requested to do a special study of nannofossil preservation states in well-chosen sequences; J. P. Réhault provided $\mathrm{CaCO}_{3}$ percentages and estimates of mineralogical content by smear-slide analysis.

We are grateful for stimulating discussion with M. Arthur, G. Blechschmidt, M. Bourbon, H. Chamley, O. de Charpal, G. Deroo, D. Habib, A. Maldonado, L. Montadert, C. Müller, W. B. F. Ryan, J. C. Sibuet, J. Sigal, and C. Williams, who generously provided advice and useful unpublished data. Helpful discussions were also held with Prof. Winterer.

We are especially grateful to Centre National Pour l'Exploitation des Oceans and Centre National de la Recherche Scientifique who made it possible for us to participate in this program and to attend a post-cruise meeting held at Lamont-Doherty Geological Observatory.

\section{REFERENCES}

Beaudoin, B., Le Doeuff, D., and Pinault, M., 1975. Les glissements synsédimentaires (slumping): un mécanisme essentiel au Jurassique terminal-Néocomien dans le SE de la France, Ninth International Congress of Sedimentology, Nice, v. 6, p. 221-228.

Berger, W. H. and Johnson, T. C., 1976. Deep sea carbonates: Dissolution and mass wasting on Ontong-Java Plateau, Science, v. 192 , p. 785-787.

Bouma, A., 1962. Sedimentology of some flysch deposits: $A$ graphic approach to facies interpretation: Amsterdam (Elsevier).

Brouwer, J., 1965. Agglutinated foraminiferal fauna from some turbiditic sequences, Proc. K. Nederl. Akad. Wetensch., v. 68, p. 309-334.

Dupeuble, P. A., Réhault, J. P., Auxiètre, J. L., Dunland, J. P., Pastouret, L., 1976. Resultats de dragage et essai de stratigraphie des bancs de Galice et des montagnes de Porto et de Vigo (marge occidentale ibérique), Marine Geology, v. 22 , p. $37-45$.

Hesse, R., 1975. Turbiditic and non turbiditic mudstones of Cretaceous flysch sections of the East Alps and other basins, Sedimentology, v. 22, p. 387-416.

Kuenen, Ph. H., 1968. Turbiditic currents and organisms, Eclogae Geol. Helv., v. 61, p. 525-544.

Maldonado, A., and Stanley, D. J., 1975. Nile Cone lithofacies and definition of sediment sequences. Ninth International Congress of Sedimentology, Nice, v. 6, p. 185-191. 1976. Late Quaternary sedimentation stratigraphy in the strait of Sicily, Smithsonian Contrib. Earth Sci., v. 16 , p. 73.

Montadert, L., Roberts, D., et al., 1976. Glomar Challenger sails on Leg 48, from Brest to Aberdeen, Geotimes, v. 21, p. 19-22.

, in press. Rifting and subsidence on passive continental margins in the North East Atlantic, Nature, v. 266 , no. 5618 , p. 305-309.

Mutti, E. and Ricci Lucchi, F., 1972. Le torbiditi dell'Appennino settentrionale: introduzione all'analisi di facies, Mem. Soc. Geol. Italiana, v. 11, p. 161-199.

Remane, J., 1970. Die Entstehung der resedimentaten Breccien in Obertithon des Subalpinen Ketten Frankreichs, Eclog. Geol. Helv., v. 63, p. 685-740.

Ricci Lucchi, F., 1975. Depositional cycles in two turbiditic formations of Northern Apennine (Italy), J. Sediment Petrol., v. 45, p. 3-43.

Rupke, N. A. and Stanley, D. J., 1974. Distinctive properties of turbiditic and hemipelagic mud layers in the Algero- 
Balearic basin, Western Mediterranean sea, Smithsonian Contrib. Earth Sci., v. 13.

Ryan, W. B. F. and Cita, M. B., 1977. Ignorance concerning episodes of ocean-wide stagnation, Marine Geology, v. 23, p. 197.
Van Stuijvenberg, J., Morel, R., and Jan du Chene, J., 1976. Contribution a l'etude du flysch de la region des Fayaux (Préalpes externes vaudoises), Eclog. Geol. Helv., v. 69, p. 309-326.

Weidmann, M., 1967. Petite contribution à la connaissance du flysch, Bull. Lab. Geol. Lausanne, v. 166, p. 1-6. 